\title{
To Compare Information and Communication Technology on the Employment of Two Industries Yazd and Kerman (Panel Data Approach)
}

Ali Raeispour ${ }^{1}$, Somayeh koochakzadeh ${ }^{2}$ and Hajar AsnsAshari ${ }^{3 *}$

${ }^{1}$ Assistant and Member of the Faculty of Kerman University, Iran

${ }^{2}$ Facualy Member of Vali-e-Asr University of Rafsanjan, Iran

${ }^{3} \mathrm{PhD}$ Student Economics, University of Sistan and Baluchestan, Iran

\begin{abstract}
Recent decades, Information and communication technology has created inhuman life great Changes. So that all aspects of human life virtually encompass and even employment is not immune to these developments. Employment is one of the most important macroeconomic variables. In this study we compared the effects of information and communication technology on employment industries Yazd and Kerman provinces. The study included two provincia panel data from various industries since the 2009-2012. Results showed that the information and communication technology industry has a direct and significant effect on employment of the two provinces of Yazd and Kerman This result demonstrates the importance of information and communication technology and trying to expand in the country and is helping to create jobs.
\end{abstract}

Keywords: Information and communication technology; Employment; Panel data

\section{Introduction}

OECD definition of information and communication technology is defined as the sum of manufacturing and service industries to maintain, transmit and display data and information electronically is used. Technological revolution with the rapid improvement of the quality of the equipment and the software is known by coming with a very larger education in prices. Information and communication technology has a dual role in the economy Inputs for users and outputs for producer of information technology and communications industries. Firms maximize profits by observing the relative price of their placement equipment, information and communication technology, software and services react rather than other goods and services. There for information and communication technology is achieved from distinctive three-part computer interaction, information and communication [1].

Information and communication technology has dual role in the economy. On the one hand, it is suggested as input to user and on the other hand, information and communication technology industry is output for manufacturers. Technological revolution is known with rapid improvement in the quality of equipment and software, along with a sharp decline in prices [2]. Thus, firms whose aim is the maximum profit replace the equipment, software and services so they can react to these changes with the rapid advancement of technology to enhance their own interests. The main conditions for the development to information technology is special are test and efficient, the shortage of staff is a major factor in the lack of technological development. The world is now passing and changing desirable status to the status quo. So we can expect a variety of careers in the information technology field is created. Developing countries are in urgent need for information technology specialists to have their employment. Apart from the issue of the establishment of training courses of reeducated people who can communicate in the digital age will not have sufficient skills and abilities [3]. Information and communication technology at the same time creats employment, it has been employment de bugger. The evidence indicates that acts as a catalyst for economic growth and employment. When daily activities are mechanized and productivity increases. Production costs and delivers will reduce. In other words, final price will decline for buyer. And consequently, the demand for buying increases. The information technology has led to accurate and timely information has always been available to applicants and it enables them to make timely and better decisions or decision-making. This would reduce its share of costs, Profit increases and economic growth facilitate. It is a fact that due to industrial activity, demand for labor in some industries reduces. Although the other hand, new jobs are entering the labor market. Some of these jobs include web design, expert web main tenant and management bases, expert systems, multimedia, satellite transmission technicians, technician global positioning systems, and electronic commerce professionals. These jobs require knowledge, skills and capabilities. Sometimes in some countries, there are no current or previous job description [4] The fundamental question that this study attempted to be answered can be stated as follows: Is the development of the information and communication technology industry in the province of Yazd and Kerman to increase employment?

\section{Basics Theoretical}

To the knowledge of the technology that is used to design or manufacture a product or set of services needed [5]. Askaramvtzy defines information and communication technology technologies to build the collection, storage, exchange and use of information in various forms of business data, voice conversations, still images and an Imation's, multimedia presentations and other forms that have yet to unveil. Information and communication technology is a network of production management, knowledge processing, distribution and optimal use of information in order to enhance system performance [6]. Lucas is defined as information and communication technology information and communication technology is defined as the information and communication technology technologies to all types of processing and storing information electronically. For this purpose, the equipment, such as computers, communications equipment and

*Corresponding author: Hajar AsnsAshari, PhD Student Economics, University of Sistan and Baluchestan, Tel: 09131968494; E-mail: esna.hajar@gmail.com

Received January 29, 2015; Accepted February 24, 2015; Published March 04 2015

Citation: Raeispour A, Koochakzadeh S, AsnsAshari H (2015) To Compare Information and Communication Technology on the Employment of Two Industries Yazd and Kerman (Panel Data Approach). Int J Econ Manag Sci 4: 239 doi:10.4172/2162-6359.1000239

Copyright: (c) 2015 Raeispour A, et al. This is an open-access article distributed under the terms of the Creative Commons Attribution License, which permits unrestricted use, distribution, and reproduction in any medium, provided the original author and source are credited. 
networks, fax machines and electronic packages used to manage [6]. Based on the theory of economic growth, increased production factors can only lead to the increased production and employment. And then, in the absence of technological progress, production efficiency will reduce; Hence, an increase in factors of production (capital) can total one increase production. But advances in technology and the law of diminishing re turns is not the transfer function can generate output and employment growth, and thus unemployment had a reduction [7].

\section{History Research}

Several studies in different countries and also in Iran to Evaluation of information and communication technology have been the case in the following. Merical in a study to evaluate the impact of in novation on employment in Estonia at the firm level and industry. Results of the study showed that the information and communication technology industry and information and communication technology firms has a positive effect on employment levels, producing has a more positive effect on employment levels. Lachenmaier [8] studied the effects of technology on employment that the study concluded that the level of technology firms has a positive effect on employment Effects of technology in the production process of its effect on the production. Product innovation creates new products in the market that creates new demand. The increased demand for labor will increase employment but the innovation process is meant to improve production processes Harrison et al. [9]. paid to investigate the impact of information and communication technology on firm-level employment (France, Germany, Spain and England). The results show that information and communication technology, changes in employment creates, But Compensation by a decline in prices caused by the impact of information and communication technology on employment is positive. Hagén and Zeed [10] using data from 2,752 firms with over 10 employees in industry and services in Sudan Using the production Cobb-Douglas function paid to study the effect of employees computer, dummy variable for broadband access as an approximation of information and communication technology. Control variables used in the study were the size of firm by number of employees, ownership type and composition skills. The results in dictate that in the industrial sector $10 \%$ increase in labor supplied to the computer makes $3 / 1$ percent increase in labor productivity and band width increases $6 / 3$ percent of labor productivity. Kaushalesh [11] employment growth and electronic work studied that Concluded the arrival of new technologies will not necessarily result in lost jobs. Following the arrival information and communication technology, employment in all firms surveyed had significant growth that main growth in employment was related to skilled workers Matteucc and Sterlachini [12]. The effect of information and communication technology on employment growth in the industries Italian studied, the results showed that the information and communication technology -producing industries have a Significant employment growth than industries using information and communication technology and the information and communication technology industries that do not use it. Rasully negad, and Nougy [13] studied to the effect on employment of communication technology using vector error correction model that the results of this study showed that communication technology is a short-term negative effect on employment but in the long run, this will have a positive effect. Mahmoud zadeh and Asadi [1] the effects of information and communication technology in economic growth of labor productivity was investigated. The results showed that the productivity of capital, non- information and communication technology and information and communication technology and human capital have a positive effect on labor productivity of the economy. Moshiri and jahangard [14] studied the effects of information and communication technologies on productivity and economic growth of Iran, This study consists of two parts, in the first part of the study are discussed to test the relationship between information and communication technology and economic growth. The result simply the existence of a non-significant but weak positive relationship between economic growth and information and communication technology. In addition, studies to pay about the impact of information and communication technology on firm performance conducted, Due to lack of data and information, is used Substitute or a poor approximation of them ensured application of information and communication technology. In the study, according to the census questions of industrial workshops ISC the variables used appropriate criteria to demonstrate how they are using information and communication technology in industrial enterprises.

\section{Materials and Methods}

The combined data set is called, based on cross-sectional observations by a number of variables $(\mathrm{N})$ during the period $(\mathrm{T})$ specified are examined. Baltagi [15] With the introduction of one-sided and two-sided error component model, joins the panel data regression model is as follows: $\mathrm{t}=1, \ldots \mathrm{T} æ \mathrm{i}=1, \ldots, \mathrm{N} ; y_{i t}=\alpha+X_{i t}^{\prime} \beta+u_{i t}$

In the above equation is show the cross (households, firms, countries, etc.) while t represents time. $\alpha$ is a scalar, $\beta$ vector is $k^{\star} 1$ and is $X_{i t}$ the it observation for explanatory variable $\mathrm{k}$. Baltajy believes that the most regression models with panel data use, one-way error component model for disturbing elements over time. $u_{i t}=\mu+v_{i t}$ In the above equation $\mu_{i}$ is an individual specific Intangible effect and does not change with time. While shows $v_{i t}$ the residual error and is known as part of the usual regression disturbance about the fixed effects $\mu_{i}$ are assumed constant parameters that must be estimated.

\section{Diagnostic tests}

Hausman test of the null hypothesis, in dictating a lack of correlation between the explanatory variables and the disturbance that if this assumption is accepted, the method of random effects is accepted too and otherwise, the fixed effects method will be accepted. To determine the type of model in combination data are used of different tests. The most common is Chow test that use for fixed effect model Against model data integration, Hausman test for fixed effects versus random effects models using LM test for random effects models using the model integration. Chow test for the merged model against the fixed effects model will perform. The assumptions for this test-is as follows: $\mathrm{H}_{0}$ : Pooled Model;

\section{$\mathrm{H}_{1}$ : Fixed effect Model}

The first hypothesis is based on the constrained values and against assumption is based on unconstrained value. Chow test statistic based on the sum of squared errors of the constrained model and

unconstrained model is as follows: chow $=\frac{\frac{\mathrm{RSSR}-\mathrm{RSS} \text { uR }}{\mathrm{N}-1}}{\frac{\mathrm{RSSUR}}{\mathrm{NT}-\mathrm{N}-\mathrm{K}}}$

This statistic has the F distribution with degrees N-1 and NT-NK is Liberation. Static tests are the most important test for estimating the regression with reliable coefficients. To avoid the creation of spurious regression is used from static tests. 


\section{Hausman test}

Based on the Hausman test, difference between fixed effects and random effects estimators approach, is considered as the null hypothesis thus rejection of the null hypothesis indicates the fixed effects method. In this test, the null hypothesis indicates a lack of correlation between the explanatory variables and the disturbance that if this assumption is accepted, the method of random effects will be accepted and fixed effects method is accepted otherwise. In this study, the following equation by Matthews and As tvlachyny conducted in Italy in 2003 is stated as follows: $\ln L=C-a_{1} \ln W+a_{2} \operatorname{Ln} R+a_{3} \operatorname{Ln} Q+$ $a_{4} \operatorname{LnICT}$ Where $\mathrm{W}$ is the wage, $\mathrm{R}$ cost of capital (interest rate), $\mathrm{Q}$ is the added value and information and communication technology is information technology and communications standards. The data of the years 2009-2012 as a combination of two different industries Yazd and Kerman Province is collected.

\section{Results and Discussion}

Based on the results of static tests boys and Shane, all variables, employment, wages, interest rates, value added and information and communication technology represents the unit root level and thus it is not static. First-order difference variables were statistically significant at 5 and $1 \%$ and the null hypothesis is excluded. Thus, these variables are stationary first order. F test Lymer, for industry Kerman and Yazd provinces respectively $31 / 5$ and $02 / 6$ obtained and show the way fixed effects model is adopted against the integrated model. Using the Hausman test to choose between fixed effects and random effects, It was clear that the null hypothesis is can be rejected based on the adjustment coefficients so this method is accepted fixed effects that are considered in Table 1.

Yazd and Kerman provinces Industry fixed effects model estimation results of the equation (1) and(2) is obtained the following:

$$
L L_{\text {kerman }}=-0.40+0.63 L Q+0.27 L I C T-0.5 L R-0.52 L W
$$

$$
\mathrm{t}
$$

The fixed effects method assumes that industries have fixed intercept and all industries have negative and different intercept but it can be seen that the absolute value of the interception Yazd, intercept is larger than Kerman industry that indicates the manufacturing sector is more advanced and more successful than Kerman and it has had the largest performance in non-oil export.

$$
L L_{\text {yazd }}=-3.52+0.94 L Q+0.19 L I C T-0.41 L R-0.66 L W
$$

$$
\mathrm{t}(10.56) \quad(1.56) \quad(2.66) \quad(-1.81)
$$

LQ: $\log$ of value added industries provinces, LICT: $\log$ of the information and communication technology industry in two provinces, LR: $\log$ of interest rates, LW :logarithm of wages between industries, LL: log of industry employment in two provinces. As can be seen, all variables are significant. High $\mathrm{R}^{2}$ indicates a good explanatory power of the model variables and shows the fitted regression in the Kerman province, $86 \%$ and $97 \%$ in Yazd represents the total employment of Yazd and Kerman provinces. T-statistic is significant for all four variables. And show that, for every four variables have a significant

\begin{tabular}{|l|c|c|}
\hline Hausman test & Amount & Probability \\
\hline H Hausman test (Kerman equation) & $14 / 00$ & 0.01 \\
\hline Hausman test (Yazdequation) & $13 / 5$ & $0 / 03$ \\
\hline
\end{tabular}

Table 1: Hausman test to test the hypothesis of random or fixed effects model, Source: research findings. effect on the dependent variable. Thus the equations (1) and (2) can be seen, that production has a direct relation with employment. With increasing production is increasing employment too. Provinces with higher capacities, greater ability to achieve economies of scale and by increasing exports, according to the relative advantages of the two provinces can increase employment. Capacity of every province are determined based on the quantity and quality of factors of production. At any moment of time, Production capacity for constant volume of production factors, the combination and technology are fixed. But over time, factors of production are expanded. Yazd has more coefficient of production. It shows that 1 percentage change in production increases $94 / 0 \%$ in employment. But in Kerman province shows a percentage change in the size of production increase $63 / 0 \%$ in employment. Interest rate is inversely related to the employment in industries reducing the interest rate increases investment. This will lead to more employment in each province. However the impact on interest rates on employment are different. In Kerman province, a percentage reduction in interest rates increase as much as 50/0\% employment. In Yazd province a percentage reduction in interest rates as of $41 / 0 \%$ to increase employment. Wage has had negative relationship employment in tow provinces. Reducing the wages employers demand for labor increases. It will also make employment. In province Kerman as a percent reduction in salary, 52/0 will increase the employment rate and in Yazd a percent reduction in salary as well as a 66/0 increases employment.

In Kerman province impact of ICT on employment is direct and significant, by increasing of the ICT industry in the manufacturing sector of this province still need for labor and this variable that is associated with increasing production through innovation, demand for labor and there by employment increase. Productive innovation is changes in the mode of production is presented new products. That through offset by increased demand for labor in this province. A percentage change in ICT can be increased as much as $27 \%$ Employment rate. Innovative means to change in the production process due to the use of ICT there by increasing the demand for labor and in other words, it causes to increase in unemployment in other words, a percent increase in the size of ICT increases employment as much as $19 \%$. Due to technical coefficients of equations (1) and (2), effect of this variable on industry employment in Kerman is more than yazd. In these two province sare considered ICT industry in the manufacturing sector as an input along with other factors of production, improves production process, capital deepening, labor quality technological progress. The implications of the effects increase the level of industrial and economic growth, productivity and consumer welfare of consumers in the province.

\section{Suggestions}

The main objective of this study was been determining the effect of ICT on employment in the two that you can see the impact of ICT on employment is positive in these two provinces. Two of these provinces should follow ICT investments with long-term prospects for creation competitive networks and developing software and hardware. This provinces also investing in ICT, infrastructure of the basis should provide for the effectiveness of ICT. In this regard, it is necessary complementary factors such as technical infrastructure, human capital, telecommunications, legislative and commercial freedom to capture the benefits of ICT to provide.

\section{Acknowledgement}

This article is drawn from are search project funded by the Research Council of Islamic Azad University we would like to thank the deputy. 
Citation: Raeispour A, Koochakzadeh S, AsnsAshari H (2015) To Compare Information and Communication Technology on the Employment of Two Industries Yazd and Kerman (Panel Data Approach). Int J Econ Manag Sci 4: 239. doi:10.4172/2162-6359.1000239

\section{References}

1. Mahmoud zadeh M, Asadi F (2005) ICT infrastructure and service sector employment Iran. Journal Economy and new Trade. No3.

2. Pohjola M (2000) Information Technology and Economic Growth A Cross Country Analysis, World Institute for Development Economic Research, Research paper 173

3. Naserzadeh H (2001) Check the status of technology in Iran, Job opportunities arising from technology. Tehran conference on information technology in employment.

4. Kurzweil R (1999) The Age of Spititual Machines: When Computers Exceed Human Intelligence, New York: Viking Publishers.

5. Fakour B, Ansary M (2010) Evaluation methods and technology resources at small firm select to Iran. Journal of Science and Technology. 2(4).

6. Hegbar Kiani K, Akhavan SH (2007) The effect of ICT on employment industries Tehran, Light Peak Humanities 5(4).

7. Afshari Z, Ramezani Fa (2006) Impact of information technology on women's employment (Cross-country). Social Studies Women's Psychological 10.

8. Lachenmaier S (2007) Effects of Innovation on Employment: A Dynamic Panel
Analysis, IFO Institute Economic Research at the University of Munchen, Germany $p 3$.

9. Harrison R (2006) Does Innovation Stimulate Employment? A firm Leve Analysis using comparable micro data from four countries.

10. Hagén HO, Zeed J (2005) Does ICT Use Matter for Firm Productivity?, Yearbook on Productivity 2005 Statistics, Sweden p 5-30.

11. Kaushalesh $L$ (2004) Growth of employment and the adoption of E-business Discussion Paper Series, United Nation University.

12. Matteucci N, Sterlachini A (2003) ICT and Employment Growth in Italian Indastries.

13. Rasully negad E, Nougy M (2009) Impact of ICT on employment Iran. Journal of Economic. No.89.

14. Moshiri S, Jahangard E (2004) Information and Communication Technology (ICT) and economic growth of Iran. Journal of Economic Research of Iran 6 : $55-78$

15. Baltagi $\mathrm{BH}$ (2001) Econometric analysis of panel data, published by JhonWiely and Sons Ltd. 